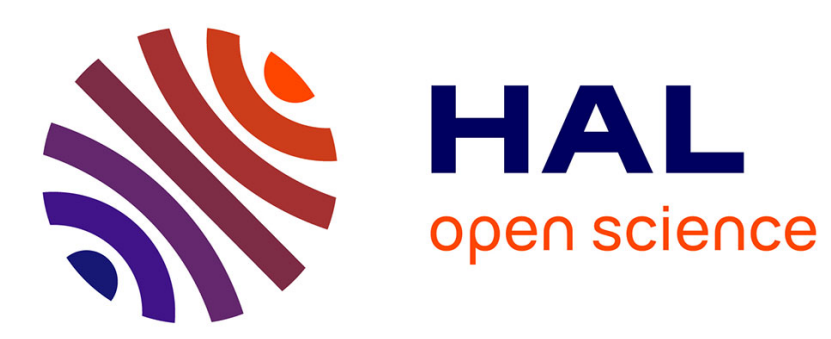

\title{
Towards Virtual Biorefineries
}

Michelle Houngbé, Anne-Marie Barthe-Delanoë, Stéphane Négny

\section{To cite this version:}

Michelle Houngbé, Anne-Marie Barthe-Delanoë, Stéphane Négny. Towards Virtual Biorefineries. 19th Working Conference on Virtual Enterprises (PRO-VE), Sep 2018, Cardiff, United Kingdom. pp.571580, 10.1007/978-3-319-99127-6_49. hal-02191156

\section{HAL Id: hal-02191156 \\ https://hal.inria.fr/hal-02191156}

Submitted on 23 Jul 2019

HAL is a multi-disciplinary open access archive for the deposit and dissemination of scientific research documents, whether they are published or not. The documents may come from teaching and research institutions in France or abroad, or from public or private research centers.
L'archive ouverte pluridisciplinaire HAL, est destinée au dépôt et à la diffusion de documents scientifiques de niveau recherche, publiés ou non, émanant des établissements d'enseignement et de recherche français ou étrangers, des laboratoires publics ou privés. 


\title{
Towards Virtual Biorefineries
}

\author{
Michelle Houngbé1, Anne-Marie Barthe-Delanoë, Stéphane Negny, \\ Laboratoire de Génie Chimique, Université de Toulouse, CNRS, INPT, UPS \\ 4, allée Emile Monso - CS 44362 - 31030 Toulouse - Cedex 4 - France \\ michelle.houngbe@inp-toulouse.fr, \{annemarie.barthe, stephane.negny\}@ensiacet.fr
}

\begin{abstract}
A key challenge for the future, biorefineries are challenged by supply and demand variability. Indeed, biorefineries structures are traditionally centralised, with static processes where inputs and outputs are strictly defined and cannot be adapted (regarding quantity, quality, purity, etc.). This paper proposes a new approach where the process is decentralised to face the challenge of the agility of biomass processing. It leads defining virtual biorefineries, in which the stakeholders (farmers, industrials) are involved in a collaborative process, where they provide operation units as services and where existing plants and equipment are reused. The design of this collaborative biomass processing should also take into account functional and non-functional factors, such as the socio-economic context, weather conditions, etc. supported by information and communication technologies. Therefore, the biomass treatment process could be quickly designed and adapted, according to the detected changes of the ecosystem
\end{abstract}

Keywords: Agility, Biorefinery, Collaboration, Industry 4.0, Model-Driven Engineering, Servitization.

\section{Introduction}

Facing global environmental challenges, the development of biosourced products and energy are the cornerstone for a sustainable future, as stated by the European strategy for the bioeconomy [1]. In this same way, one of the French Energy Transition for Green Growth Act's goals is to increase the use of renewable energies to $32 \%$ of total energy consumption in 2030, where the biomass (and the biomass processing) will occupy a leading position [2].

Biomass is organic material that comes from plants and animals, and it is a renewable source of energy: wood and wood processing wastes, agricultural crops and waste material, animal manure, etc. Key player in the bio-based chemistry and energy, biorefinery is the "processing of biomass into a spectrum of marketable products and energy", as defined by the US Energy Information Administration [3] and Cherubini [4].

However, processing a living material like biomass is highly constrained by numerous hurdles like the biomass demand and supply irregularities, not only in terms of quantity and quality but also regarding producers' location and seasonality of the 
556 M. Houngbé et al.

production. Plus, biorefinery is an extremely specialized and rigid system, whose structure is inherited from the oil-based refineries $[5,6]$.

The entire complex transformation of biomass into bioproduct is realized by one dedicated process (composed of four major unitary operations: pretreatment, fermentation, separation, purification), in one single facility involving one stakeholder. This centralized process is dedicated to a given input biomass and given output bioproduct(s) [7]. This is another hurdle to adapt the biorefinery to face variability and to set up plants. Finally, the biomass process treatment requires heavy initial financial investments and generates significant operating costs, whereas the variability of supply threatens the proper functioning of the biorefinery. The problem underlying these observations stems from the need to provide agility to biorefineries, both at the physical system and information system levels.

If agility is now a well known topic in the manufacturing industry (especially within the frame of Industry 4.0), it is surprisingly pioneering in the chemical process industry [8].

Thus, our goal is to answer to the following research question: How can biorefineries development be fostered with providing the required agility to cope with this unstable environment?

This article is organized as follows: Section 2 presents the state of the art about the agility of biorefineries. Section 3 develops the proposal of virtual biorefinery within the frame of the ARBRE project ("Agilité pouR les BioRaffineriEs", meaning Agility foR the BioRefineriEs) that aims at providing agility to biorefineries. Section 4 details a meta model of the virtual biorefinery, before concluding.

\section{Agility of Biorefineries}

We aim to provide agility to the biorefinery, which is for the moment a centralized and highly specialized system. Within the frame of the ARBRE project (2017-2021), the agility of a system is defined as "the capacity of a system to realize, in the shortest possible lapse of time (reactivity), the detection of its inadequacy to the environment in which it evolves and the execution of the necessary adaptation" [9].

In the biomass transformation literature, the agility of the process is not a primary concern. A few articles are interested in the topic but they remain at the chemical and technological levels. Agility is then seen as a flexible plant, where a reconfiguration of the process is achieved by switching equipment inside a single standalone plant. But, if we consider the biomass transformation process in the broader sense, being more than just the chemical process and including its environment (farmers, industrials, customers, etc.) it can be seen as a supply chain. Some research works study biorefinery design from the supply chain point of view, but they focus on the optimization (cost, energy) to design a centralized process $[10,11]$.

In the manufacturing industry, the needs to reduce costs and to maximize flexibility of the supply chain can be satisfied by calling to decentralized production systems and to inter-organizational collaboration strategy. These collaborations can lead to create Virtual Enterprise or Virtual Organization [12] made by several companies to reach one (or more) common objective(s). There is a few research 
works on the collaborative networks in the biomass processing area but the network is limited to only two stakeholders [13] and/or only consider the cost of the intermediate products transport to assess the feasibility of the decentralization [14]. The inherent constraints of the biomass treatment are not discussed, like the perishable nature of agricultural products, natural deterioration, crop seasonality, etc. to propose a relevant and realistic collaboration.

Moreover, the sustainability of the existing material, its reuse, its modularity and its ease of maintenance become major stakes (as underlined by the French strategy towards the bioeconomy [5]). In the manufacturing area, the servitization of companies is the transition from the sale of products towards the sale of integrated offers for products and intangible services [15]. Dahmani and al. [16] have studied the transition of a manufactured company towards a specific type of servitization: Product, Service, System.

The degree of servitization can also be raised until the level of service economy. The service economy was initially defined by Stahel [17] as the economy "[...] which optimizes the use or the function of goods and services, concentrates on the management of the existing wealth, in the form of goods, knowledge and the natural capital. The economic objective is to create the highest value in use possible during the longest possible time consuming the least material resources and possible energy". If servitization is not applied yet to the biomass processing industry, a bridge can be built between the servitization and cooperation economy (considered as the first level of the service economy). In France, one farmer out of two takes part into a cooperative association to share the use of equipment and thus share the investment in equipment and the hiring costs of the operators [18].

Agility also relies on the ability to ensure situational awareness [19]. Considering the high degree of connectivity of the agricultural sector (eFarming), the availability and the volume of exogenous data sources about weather conditions, territories (e.g. OpenData), and the rise of new technologies producing amounts of data, there is a need for data, information and knowledge management to enhance situational awareness.

Moreover, Camarinha-Matos and al. [20] showed that collaborative networks are strongly affected in terms of structure, process and mechanisms by technologies from Industry 4.0, such as Big Data or Cyber Physical System. From the biomass processing point of view, Information and Communication Technologies (ICT) would support not only the characterization of the stakeholders (farmers, industrials, etc.) and their services but also the whole ecosystem (climate event, market event, etc.) to anticipate their consequences and react, either when designing or running the biorefinery.

Research works and projects conducted on supply chain agility and Industry 4.0 are applied to the manufacturing industries, and even institutions and administrations. But this is not the case for the biomass process industry where collaborative behavior and servitization, supported by ICT have never been established yet [10]. 


\section{A Platform to Design and Monitor Virtual Biorefineries}

Based on the previous observations, the French funded project ARBRE proposes to create a framework and a software platform to design and monitor virtual biorefineries.

First, the aim is, through a systemic approach, to model the biorefinery structure as a System of Systems where the chemical process is not performed on a single standalone unit anymore. With the servitization of the chemical plants, each unitary operation equipment would not only be reused for various processes (instead of being dedicated to a single transformation process), and this would allow the processing of various kinds materials and products, as well as a reconfiguration of the process according the variability (quality, quantity, demand, supply, etc.).

This lead us to define the concept of virtual biorefinery (Figure 1) to provide the required agility to biomass processing: a collaborative process, involving the farmer, the facilities and the consumer, at both the physical and information system levels, which is built according the chosen chemical process and the chosen bioproduct and taking into account the context, the partners and their services and the performance. According to the objectives and the constraints, the role of the stakeholders can evolve.

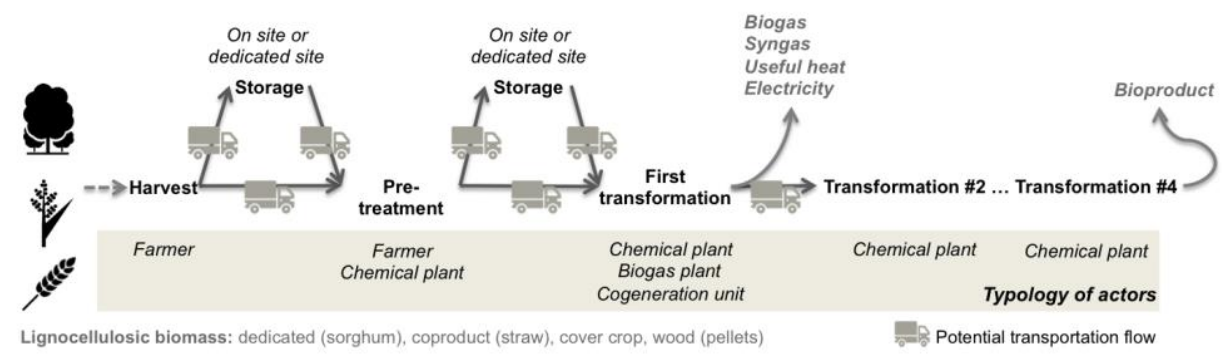

Fig. 1. The virtual biorefinery, as proposed in the ARBRE project.

The methodology of the ARBRE project is based on knowledge management and collaborative process design, following the methodology described in [21]. It will be implemented as a software platform, available to the stakeholders (Figure 2). These ones will describe their services (from both functional and non-functional points of view) and their objectives on the platform. Exogenous data will be used to describe the environment.

Based on the gathered knowledge, collaborative opportunities for biomass processing and the associated chemical transformation process can be deduced. Then, mining the directory of available partners and their services, along with their functional and non-functional requirements, the collaborative process is deduced. 


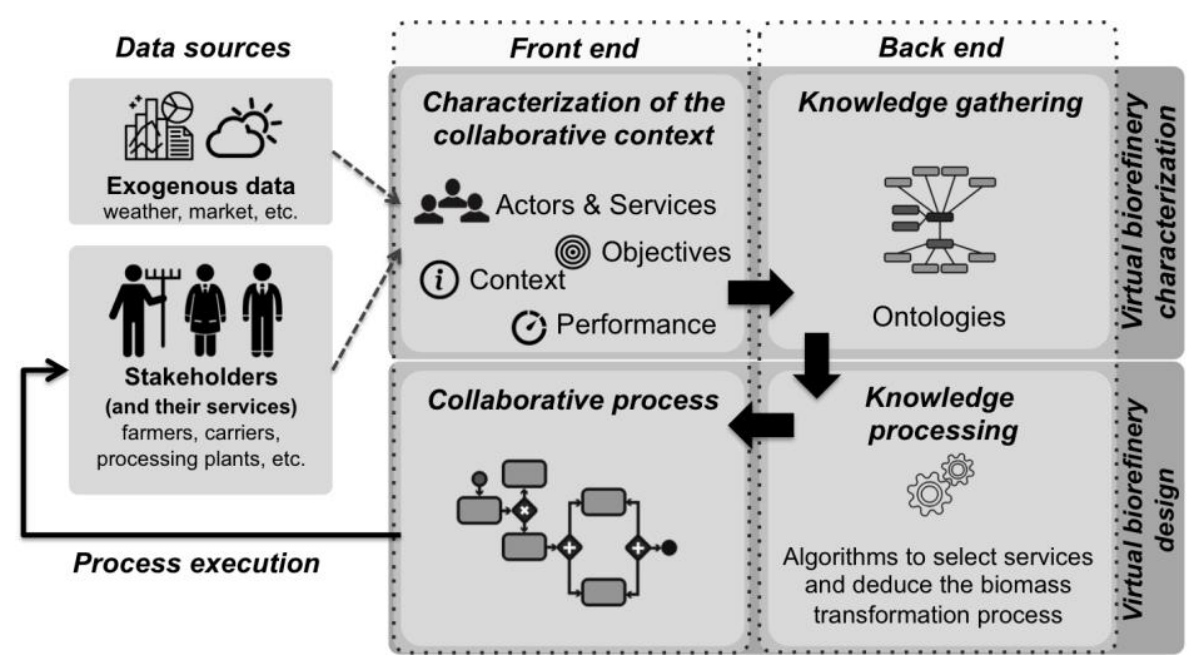

Fig. 2. The ARBRE software platform architecture, to design and monitor the virtual biorefinery.

\section{A Meta Model for Virtual Biorefineries}

Designing the collaborative network to build the virtual agile biorefinery, whatever the type of biomass, requires to describe a generic collaborative process for biomass transformation and thus to gather relevant knowledge.

In other words, it is necessary to collect data and information about the collaborative virtual biorefinery system: actors and their services (e.g. $\{$ Farmer A\}: \{harvest straw / pace: 3 ha. $\mathrm{h}^{-1}$ \}); collaborative objectives (e.g. produce biodiesel with straw); context (e.g. weather forecast, biomass physical properties and location, road network, etc.).

To achieve this, we will adopt a Model Driven Engineering approach, which enables to raise the level of abstraction among a complex and specific system (as the biomass processing) and experiment the virtual biorefinery, before designing it. The knowledge about the collaboration objectives, the actors, the services, the context, the threats and opportunities, and the performance will be represented as a meta model. To this end, we will use the CORE meta model defined in Benaben and al. [22], as presented in Figure 3 [23]. 


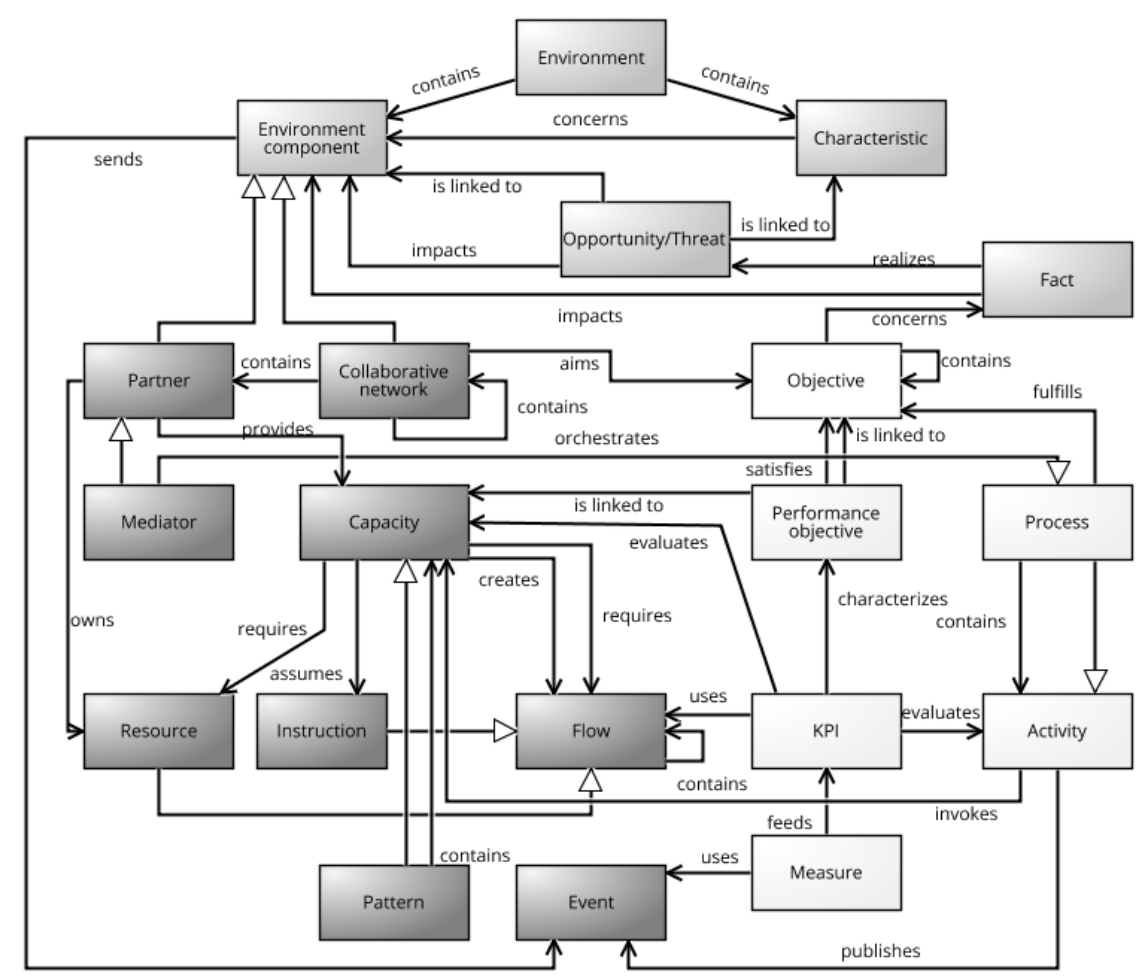

Fig. 3. The CORE meta model (from [22, 23]): Context (middle grey), Partners (dark grey), Performance (light grey), Objectives (white).

This meta model describes the main concepts of any collaboration, including objective, context, partners and performance. The interesting characteristic of this meta model is its ability to be specialized to fit with a given business domain. It has been successfully used into several research works and projects from crisis management [9] to trade exchanges [21].

Based on this CORE meta model, we propose to extend it into a meta model layer dedicated to the virtual biorefinery as envisioned in the ARBRE project.

The design of this first attempt of a meta model layer was supported by the literature and return of experience from industrial cases. For the moment, we focus on the context, partner and objective packages. The performance package will be studied in further works. Our proposal is shown and described below.

\section{Context package}

The context sets the characteristics of the collaboration environment (Figure 4). The deposit is central in the context and inherits from the environment component concept from the CORE package. 


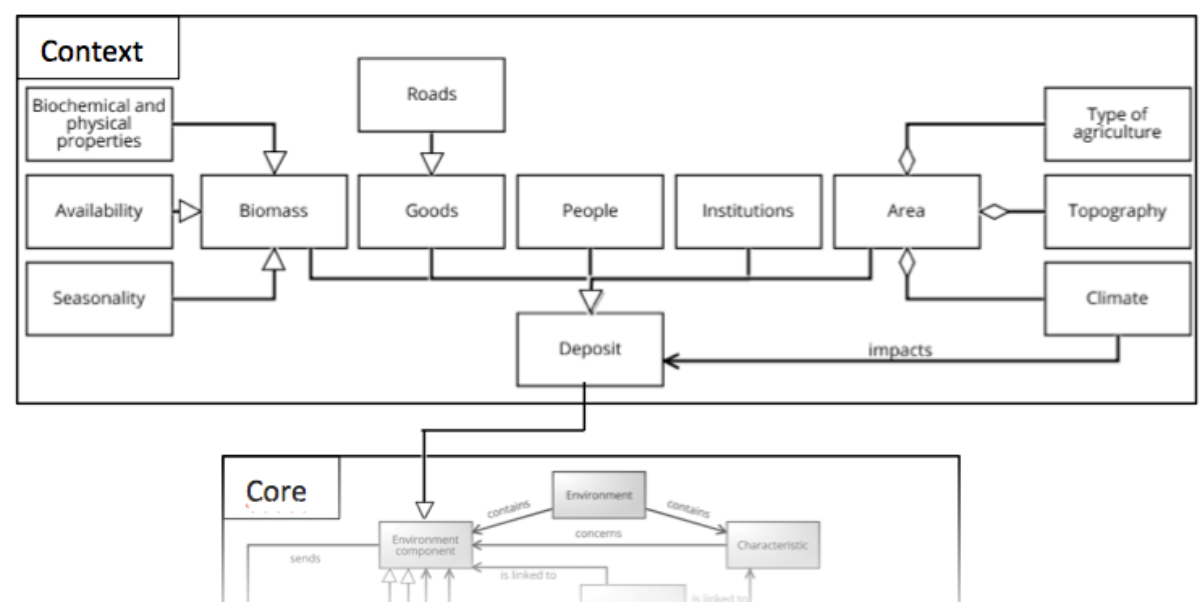

Fig. 4. Focus on the Context package of the virtual biorefinery meta model.

First of all, the deposit contains the biomass, which is characterized by biochemical and physical properties (hygrometry, chemical composition, residual traces of plant protection products, etc.), which is related to the quality of the biomass, its availability relating to the volume and a seasonality which imposes the harvesting time.

Then, the deposit is located in a geographical area determined by a climate and a topography and where a type of agriculture (extensive or intensive agriculture, organic farming, etc.) is performed.

The climate impacts also the deposit according to the climate events (rainfalls, drought, storm, etc.). Other specialized elements compose the deposit.

Goods concern the required installations, as roads, to determine the accessibility to the deposit.

People represent the extended community who will be decisive regarding the social acceptability of the virtual biorefinery project.

Finally, the governing and decisional bodies settled on the deposit are represented by the institutions concept.

\section{Partner package}

The partners constitute the collaborative network (Figure 5). Each actor inherits from the CORE partner concept and provides information about their capacity to realize a service according to their expertise and skills.

In a servitization context, their resource enables to characterize the service they will realize, according to an identified unitary operation, in the biomass processing.

The mediator is a specific actor in charge of the overall coordination of the collaboration, as a conductor in an orchestra. We can note that usually the mediator is 
562 M. Houngbé et al.

a non-human actor, part of the Information System and relying on Service Oriented Architecture paradigm.

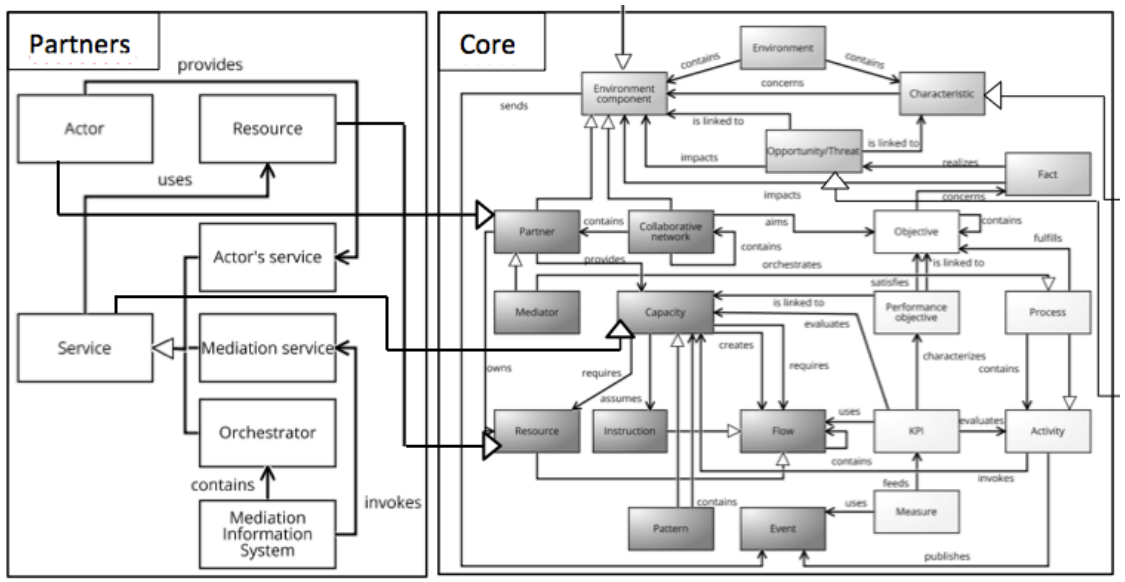

Fig. 5. Focus on the Partners package of the virtual biorefinery meta model.

\section{Objectives package}

The aim of this package is to define the objective of the virtual biorefinery (Figure 6) which is the biomass processing.

This objective responds to the market, which states both supply and demand and also the competitive conditions among the stakeholders.

The biomass processing is linked to impact factors that can positively (opportunity) or negatively (threat) impact the collaborative process. They are composed with the financial factor (e.g. evolution of market price), technological factor (e.g. new intensified unitary operation equipment, new biomass material) and ecological factor (e.g. environmental impact of biomass processing on the deposit).

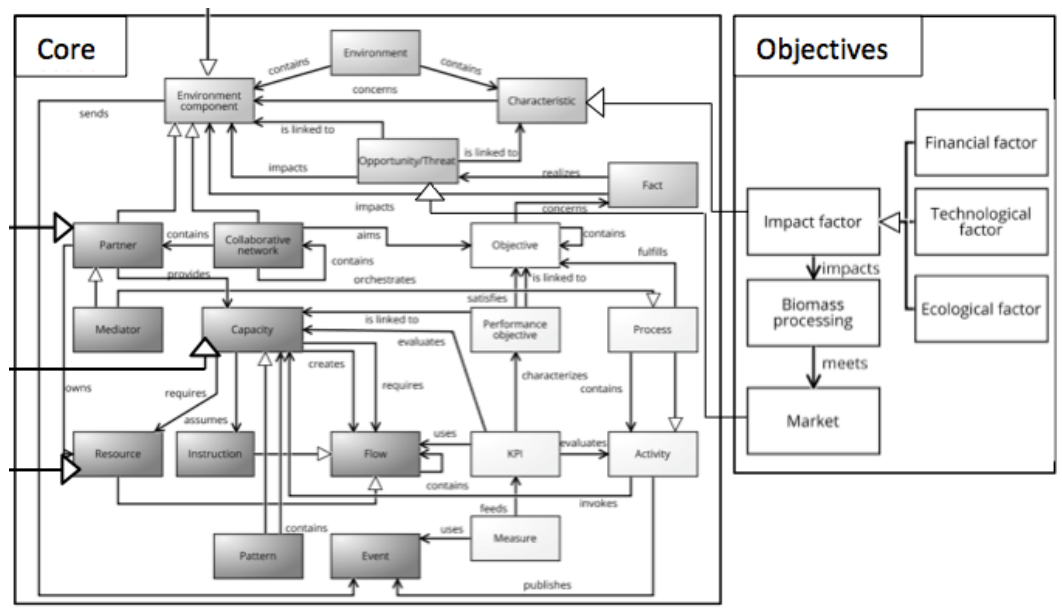

Fig. 6. Focus on the Objectives package of the virtual biorefinery meta model. 


\section{Conclusion}

The ARBRE project aims to overcome the traditional and disciplinary-centered view of the biomass process industry that leads to a lack of agility facing changes, whatever their nature. The objective is to develop a virtual biorefinery framework, through a systemic view, enabling to: create synergies among the stakeholders (by using information and communication technologies), improve the efficiency of the dynamic of the collaborative network and enhance the interactions between the biomass processing stakeholders and the environment.

This paper has proposed a meta-model of a collaborative network dedicated to the biomass processing, taking into account the characteristics of this living material and its environment. This meta model is the cornerstone to design the virtual biorefinery envisioned by the ARBRE project. It will allow to collect and to process the necessary knowledge about the system, to support the deduction of the collaborative biomass processing and network of actors, and to monitor the virtual biorefinery.

This meta-model supports the modeling of a biorefinery seen as a collaborative network, adapted to the detected opportunities and to the characterization of the whole system (actors, context, etc.). In other words, it supports the modeling of an agile biorefinery. In addition to the acceleration of the set up of the biomass-processing infrastructure, this meta-model would also support the continuous monitoring of the biorefinery. If any element of the system evolves (actors, services, context, objective, performance), it would be possible to detect a deviation and to support decisionmaking facing the adaptation of the biorefinery to these new parameters.

Further works on this meta model will focus on refining it by adding the performance package (identifying the Key Performance Indicators) and assessing it on realistic industrial use cases of lignocellulosic biomass processing in the South of France area (provided by one of the project's partners).

Acknowledgments. These research works are funded by the French Research Agency (ANR) regarding the research project ARBRE [Grant ANR-17-CE10-0006], 20172021. ARBRE aims to develop French biorefineries as agile collaborative networks and supported by the Industry 4.0 paradigm. The authors would like to thank the project partners for their advice and comments regarding this work.

\section{References}

1. European Environment Agency: Innovating for Sustainable Growth: a Bioeconomy for Europe. European Union, Luxembourg (2012).

2. Assemblée Nationale, Sénat: LOI n ${ }^{\circ} 2015-992$ du 17 août 2015 relative à la transition énergétique pour la croissance verte. (2015).

3. de Jong, E., Jungmeier, G.: Biorefinery Concepts in Comparison to Petrochemical Refineries. In: Industrial Biorefineries \& White Biotechnology. pp. 3-33. Elsevier (2015).

4. Cherubini, F.: The biorefinery concept: Using biomass instead of oil for producing energy and chemicals. Energy Conversion and Management. 51, 1412-1421 (2010). 
564 M. Houngbé et al.

5. Le Déaut, J.-Y., Courteau, R., Sido, B.: De la biomasse à la bioéconomie : une stratégie pour la France. SENAT (2016)

6. Balan, V.: Current Challenges in Commercially Producing Biofuels from Lignocellulosic Biomass. ISRN Biotechnology. 2014, 31 (2014).

7. Clark, J.H., Deswarte, F. eds: Introduction to Chemicals from Biomass. Wiley, UK (2015).

8. Hossiso, K.W., Ripplinger, D.: The Value of Switching Production Options in a Flexible Biorefinery. Agricultural and Resource Economics Review. 46, 146-173 (2017).

9. Barthe-Delanoë, A.-M., Truptil, S., Bénaben, F., Pingaud, H.: Event-driven agility of interoperability during the Run-time of collaborative processes. Decision Support Systems. 59, 171-179 (2014)

10. Yue, D., You, F., Snyder, S.W.: Biomass-to-bioenergy and biofuel supply chain optimization: Overview, key issues and challenges. Computers \& Chemical Engineering. 66, 36-56 (2014)

11. Feng, Y., D'Amours, S., LeBel, L., Nourelfath, M.: Integrated Bio-Refinery and Forest Products Supply Chain Network Design Using Mathematical Programming Approach Semantic Scholar. In: Integrated Biorefineries: Design, Analysis, and Optimization. pp. 251-282. CRC Press, Boca Raton, FL, USA (2012).

12. Camarinha-Matos, L.M., Afsarmanesh, H., Garita, C., Lima, C.: Towards an architecture for virtual enterprises. Journal of Intelligent Manufacturing. 9, 189-199 (1998).

13. Kim, J., Realff, M.J., Lee, J.H., Whittaker, C., Furtner, L.: Design of biomass processing network for biofuel production using an MILP model. Biomass and Bioenergy. 35, 853871 (2011).

14. Bowling, I.M., Ponce-Ortega, J.M., El-Halwagi, M.M.: Facility Location and Supply Chain Optimization for a Biorefinery. Ind. Eng. Chem. Res. 50, 6276-6286 (2011).

15. Vandermerwe, S., Rada, J.: Servitization of business: Adding value by adding services. European Management Journal. 6, 314-324 (1988)

16. Dahmani, S., Boucher, X., Peillon, S.: Industrial Transition through Product-Service Systems: Proposal of a Decision-Process Modeling Framework. In: Collaborative Systems for Reindustrialization. pp. 31-39. Springer, Berlin, Heidelberg (2013).

17. Stahel, W.: The Performance Economy. Springer (2010)

18. CUMA Chiffres clés, Edition 2017. Fédération Nationale des CUMA, Paris (2017).

19. Endsley, M.R.: Toward a Theory of Situation Awareness in Dynamic Systems. Hum Factors. 37, 32-64 (1995).

20. Camarinha-Matos, L.M., Fornasiero, R., Afsarmanesh, H.: Collaborative Networks as a Core Enabler of Industry 4.0. In: Collaboration in a Data-Rich World. pp. 3-17. Springer, Cham (2017).

21. Montarnal, A., Barthe-Delanoë, A.-M., Bénaben, F., Lauras, M., Lamothe, J.: Towards Automated Business Process Deduction through a Social and Collaborative Platform. In: Camarinha-Matos, L.M. and Afsarmanesh, H. (eds.) Collaborative Systems for Smart Networked Environments. pp. 443-451. Springer Berlin Heidelberg (2014).

22. Bénaben, F., Lauras, M., Truptil, S., Salatgé, N.: A Metamodel for Knowledge Management in Crisis Management. In: 2016 49th Hawaii International Conference on System Sciences (HICSS). pp. 126-135 (2016).

23. Macé-Ramète, G., Lamothe, J., Lauras, M., Benaben, F.: A road crisis management metamodel for an information decision support system. In: 2012 6th IEEE International Conference on Digital Ecosystems Technologies (DEST). pp. 1-5 (2012). 